\section{Appreciation family support and the abilities of children with special needs to maintain personal hygiene: an Indonesian case study}

\author{
Ita Pursitasari, \\ Allenidekania Allenidekania, \\ Nur Agustini \\ Faculty of Nursing Universitas \\ Indonesia
}

\begin{abstract}
Family support is needed to empower children with special needs to maintain personal hygiene, includes information, instrumental, emotional, and appreciation support. The study design was cross-sectional, involving 84 parents of children with special needs. The study was conducted via the respondents filling out a questionnaire consisting of three sub-questionnaires. The results showed no relationship between the characteristics of children with special needs and personal hygiene; there was also no relationship between parental characteristics and personal hygiene $(\mathrm{P}>0.05)$. There was, however, a relationship between information, instrumental, emotional, and appreciation support and personal hygiene $(\mathrm{P}<0.005)$, the most influential support being appreciation support. In conclusion, there was a significant relationship between information, instrumental, emotional, and appreciation support and the ability of children with special needs to maintain their personal hygiene. The recommendations for future studies are different research methods to explore more about the types of family support.
\end{abstract}

\section{Introduction}

Children with special needs are those who have a risk of experiencing chronic conditions; developmental, behavioral, or emotional disorders; abnormalities or physical disabilities; and need health services that are more than those of typical children. ${ }^{1}$ Children with special needs are those who experience limitations or excellence, including physical, intellectual, social, and emotional types, that have a significant influence on their process of growth and development compared to other children their age. ${ }^{2}$

One study's results shows that $15.3 \%$ of the world's population, or around 978 million of the estimated 6.4 billion people in the world as of 2004, have moderate disabilities and $2.9 \%$ have severe disabilities, whereas in the population age range $0-14$ years, people with moderate disabilities number around $0.7 \%$ (13 million people) and those with severe disabilities at around 5.1\% (93 million people). ${ }^{3}$ The number of children with special needs in Indonesia is around 295,250, which is $7-10 \%$ of Indonesia's total population. ${ }^{4}$ Based on similar data, the presentation of children age $24-59$ months, about $0.53 \%$ have disabilities. 5

The ability to perform Activity Daily Living (ADL) or daily activities is important so that one can function in everyday life. 6 Children with special needs often experience problems in carrying out ADL, one of which is the personal subdomain of eating, dressing, maintaining personal hygiene, and toileting. ${ }^{7}$ Autistic children have a low level of adaptation in terms of socializing, communicating, and daily activities. ${ }^{8}$ From a retrospective method, the dental health of children with special needs in Lithuania is very poor, where $72 \%$ of the children had five damaged teeth, and as many as $27 \%$ of the children had 10 damaged teeth. ${ }^{9}$ In another study, 60 children with disabilities in Spain, 19 (31.7\%) stated that they brush their teeth twice a day, 18 (30\%) brush their teeth three times a day, and $10 \quad(16.7 \%)$ brush their teeth sometimes. ${ }^{10}$ Meanwhile, the majority of autistic children experience incompetence in self-care, eating, and dressing. ${ }^{11}$ Atopic severe dermatitis in children is caused by bathing once a day only two to three times a week. 12

Good self-care has an impact on health though the health status of those with disabilities is lower than general health. ${ }^{13}$ Some of the diseases caused due to lack of self-care are those in the mouth area, specifically from poor oral hygiene due to not brushing teeth. ${ }^{10}$ The mouth diseases that often arise are gingivitis, periodontitis, and caries. ${ }^{14}$ Another problem that arises due to a lack of self-care is the discomfort caused by dirty clothes from toileting inabilities; besides that, children with special needs are often victims of bullying, both physically and verbally. 15

Family support is very much needed by children with special needs. Family support consists of information, emotional, appreciation, and instrumental support, which are all direct provided assistance, for example, parents provide assistive devices to bathe children with special needs that are suitable for those children's needs. ${ }^{16}$ The most common support is material/instrumental, where families provide basic needs such as food, shelter, and health care. ${ }^{17}$ The main source of support for children with chronic
Correspondence: Allenidekania Allenidekania, Pediatric Nursing Department, Faculty of Nursing, Universitas Indonesia, Jalan Prof Dr. Bahder Djohan, kampus UI Depok, West Java, 16424 Indonesia

Tel.: +6221.78849120 - Fax: +6221.7864124.

E-mail: alleni@ui.ac.id

Key words: Children with special needs; family support; personal hygiene.

Acknowledgments: The writer would like to express her gratitude to all parents with disability of the children who participated in this study.

Funding: This study was supported by Hibah PITTA B 2019 DRPM UI No. NKB0484/UN2.R3.1/HKP.05.00/2019 for funding this research.

Contributions: IP substantial contributions to the conception of the work; acquisition, analysis, or interpretation of data for the work. AA and NA supervised the findings of this work; final approval of the version to be published. All authors discussed the results and contributed to the final manuscript.

Ethical approval: Approval was received from the Research Ethics Committee of the Faculty of Nursing Universitas Indonesia before the study began (No.47/UN2.F12.D/HKP.02.04/2019).

Conflict of interest: There is no conflict of interest in this study.

This work is licensed under a Creative Commons Attribution NonCommercial 4.0 License (CC BY-NC 4.0).

(C) Copyright: the Author(s), 2020

Licensee PAGEPress, Italy

Pediatric Reports 2020; 12(s1):8700

doi:10.4081/pr.2020.8700

diseases re their mothers, who teach them about disease management, safety, and how to cope with their concerns. ${ }^{18}$

The role and support of the family, especially parents, is very much needed to help make children with special needs independent. The role of parental care for children with special needs is still low at $16.1 \%$, and family and social support is as low as $12.9 \% .{ }^{19}$ Another study stated that the percentage of mentally retarded children capable of self-care activities (personal hygiene, eating, drinking, dressing, mobilization, movement, socialization) without assistance from others is $3.1 \% .^{20} \mathrm{~A}$ different study told that the ability of mentally disabled children to the toilet was $45.5 \%$, while children are totally dependent on parents and teachers to carry out defecation and childbirth. ${ }^{21}$ Another study indicated 
that parents with children with autism are taught how to toilet train their children by setting a schedule for toilet sitting, increasing their fluid intake, positively reinforcing elimination in the toilet, guiding self-initiation, and penalizing their children for failing to toilet; from all these steps, it was found that all the studied children were able to use toilets in other places, such as the home, school, and public places. ${ }^{22}$

Nurses and parents look for ways for children with special needs to pass through developmental stages with all the potential they possess. ${ }^{1}$ One way is to provide support and teach and train skills about individual needs, especially personal hygiene that must be done without help from others, to ensure independence in everyday life as individuals and social beings through education from families, schools, and communities.

\section{Materials and Methods}

This research followed a quantitative method with a descriptive analysis design and is cross-sectional because family support and personal hygiene in children with special needs were assessed simultaneously to see whether there is a relationship or not between the two. 23

The data collection technique used was a questionnaire. The study sample were parents of children with special needs who attend the Bogor City special school and Bogor District special school and are age 618 years old, amounting to 84 people. The instrument used in this study was a questionnaire consisting of three components, namely questionnaire A about family characteristics, questionnaire $\mathrm{B}$ about family support, and questionnaire $\mathrm{C}$ about personal hygiene. Family support consists of information, instrumental, emotional, and appreciation support, while personal hygiene consists of bathing and shampooing, brushing teeth, and cleaning genitalia. We measured the results using a Likert scale.

The study was conducted after passing an ethics review from the ethics committee of the Indonesian University of Nursing Faculty (FIK UI), then obtaining permission from the local education office, which together with the school identified parents who were in accordance with the inclusion criteria. The researchers provided informed consent to the respondents; if they were not willing to participate, they were able to resign.

\section{Results}

From this study, the following results were obtained: Tables 1 and 2 show no significant relationship between parental char- acteristics and the characteristics of children with special needs and the ability to maintain personal hygiene ( $\mathrm{P}$-value $<0.05$ ). Table 3 features a relationship between family support and children's with special needs ability to maintain personal hygiene, as well as other family support variables with P-value $<0.05$. The majority of family support is appreciation support, with an OR value of 17.672 (CI 5.933-52.629). This means that children with special needs with good appreciation support have a risk of 17.672 times to be able to maintain personal hygiene independently.

\section{Discussion}

The assessed children with special needs were age 6-18 years and divided into two categories, namely children age 6-12 years and children age $12-18$ years. The majority of children with special needs were 6-12 years old. The ability of children with special needs to maintain personal hygiene routines is not the same as children in general. Typical children can maintain personal hygiene in accordance with the appropriate stages of growth and development. This is certainly different for children with special needs, especially mentally disabled children, whose level of intelligence is limited and below the average age of children, such as instances where once they reach the age level of grade II or IV, they reach the mental age of preschool-level children. 24

Most of the parent respondents in this study were $35-55$ years old. People at the age of over 20 years can make decisions and play a role in educating and shaping the behavior of themselves and children. 25 People at the age of over 20 years are mature enough to parent, as parents are expected to be able to provide support to family members, especially children with special needs.

The education level of the parental respondents in this study was mostly high school. Parental education level is related to parental involvement in education and childcare, as parental education can indirectly affect the academic achievements of children because of the parents' support in the home. ${ }^{26}$ In addition, parents can become teachers at home and help their children do homework and provide other cognitive stimulation. Two of the factors that influence childcare are education and parental experience, which affect parents' readiness to carry out their duties. ${ }^{27}$ The quality of life of children with special needs is better primarily for those who are cared for by mothers with higher education and receive addi- tional social support from all family members. ${ }^{28}$

The description of family support in this study generally shows good results. The most common family support is instrumental, which can be seen in the form of equipment for personal hygiene, such as a small dipper for bathing; storing soap, toothbrushes, and glasses for gargling in a place that is easily accessible to children; and the availability of soft-bristled toothbrushes sized according to the size of the child's mouth. Children with special needs require social support, one form of which being children with intellectual impairments receiving instrumental support from their parents, such as in carrying out self-care, in addition to their parents receiving instrumental support from their biological or other close relatives. ${ }^{29}$ Family support is very helpful in minimizing psychological complaints; providing strength, motivation, and energy; and reducing uncertainty and insecurity that affect the health and quality of life of children with special needs. ${ }^{30}$

Based on the results of this study's Chisquare test, there was no significant relationship between parental characteristics, namely parents' age, education, employment, and income, and the ability of children with special needs to maintain personal hygiene. The results of the Chi-square test for the relationship between the characteristics of children with special needs and personal hygiene ability also showed no significant relationship. This is in line with self-care agents in mentally disabled children are not influenced by the characteristics of children, parents, or the environment. 20

Our results showed that there is a relationship between family support and children's with special needs ability to maintain personal hygiene at $\mathrm{P}<0.05$. From the results of this study, we found that the majority of children with special needs who receive good family support can maintain personal hygiene independently. The majority of families provide family support to children with special needs in regard to personal hygiene.

There is a relationship between information support and children with special needs ability to maintain personal hygiene. More than one-third of children with disabilities who were given information by their families brush their teeth twice to three times a day. 10 There is also a relationship between instrumental support and children with a special needs ability to maintain personal hygiene. Instrumental support is included in the health care and family economic functions. 16 The health care function can take the form of providing food, clothing, and shelter, and the 
family economic function in the form of adequate financial provision. Meanwhile, the most common family supports, namely material/instrumental, are where families really provide basic needs, such as food, shelter, and health care. 17

There is one other relationship between appreciation support and children with special needs ability to maintain personal hygiene. Appreciation support from the family can improve the psychosocial status of all family members, so children with special needs who receive encouragement and praise will feel useful and have increased self-esteem, so they are motivated to maintain their personal hygiene. ${ }^{16}$ Based on the results of this conducted research and as supported by related studies, it can be concluded that appreciation support has a meaningful relationship with increasing family support for children with special needs in maintaining their personal hygiene.

Multivariate analysis revealed that the most related variables to children with special needs personal hygiene are appreciation and information support. Appreciation support is given to another through positive expressions so that the person feels better in facing stressors. Children with special needs who receive appreciation support such as encouragement, praise, and positive reinforcement to maintain their personal hygiene will feel happy, proud, and valuable and thus motivated to actualize themselves. With the support of information, children with special needs will know how to maintain and the benefits of personal hygiene so they will want to do it Information support, meanwhile, is information provided so that children with special needs become aware of how to maintain personal hygiene.

Table 1. Distribution of the relationship characteristics of parents of children with special needs with the ability to maintain personal hygiene in Bogor $(n=84)$.

\begin{tabular}{|c|c|c|c|c|c|c|c|c|}
\hline No. & $\begin{array}{l}\text { Parent characteristics } \\
\text { variables }\end{array}$ & $\mathrm{N}$ & \% & $\begin{array}{c}\text { Perso } \\
\text { No } \\
\text { N }\end{array}$ & $\begin{array}{l}\text { ent } \\
\%\end{array}$ & $\mathrm{n}$ & $\%$ & P-value \\
\hline 1 & $\begin{array}{l}\text { Age } \\
20-35 \text { years } \\
>35-55 \text { years } \\
>55 \text { years }\end{array}$ & $\begin{array}{c}9 \\
37 \\
1\end{array}$ & $\begin{array}{l}56.2 \\
55.2 \\
100\end{array}$ & $\begin{array}{c}7 \\
30 \\
0\end{array}$ & $\begin{array}{l}43.8 \\
44.8 \\
0.00\end{array}$ & $\begin{array}{c}16 \\
67 \\
1\end{array}$ & $\begin{array}{l}100 \\
100 \\
100\end{array}$ & 0.670 \\
\hline 2 & $\begin{array}{l}\text { Education } \\
\text { Elementary school } \\
\text { Junior high school } \\
\text { High school } \\
\text { College }\end{array}$ & $\begin{array}{l}4 \\
2 \\
26 \\
15\end{array}$ & $\begin{array}{l}57.1 \\
25.0 \\
57.8 \\
62.5\end{array}$ & $\begin{array}{c}3 \\
6 \\
19 \\
9\end{array}$ & $\begin{array}{l}2.94 \\
75.0 \\
42.2 \\
37.5\end{array}$ & $\begin{array}{c}7 \\
8 \\
45 \\
24\end{array}$ & $\begin{array}{l}100 \\
100 \\
100 \\
100\end{array}$ & 0.309 \\
\hline 3 & $\begin{array}{l}\text { Job } \\
\text { Does not work } \\
\text { Works }\end{array}$ & $\begin{array}{c}6 \\
41\end{array}$ & $\begin{array}{l}66.7 \\
54.7\end{array}$ & $\begin{array}{l}66.7 \\
334\end{array}$ & $\begin{array}{l}33.3 \\
45.3\end{array}$ & $\begin{array}{c}9 \\
75\end{array}$ & $\begin{array}{l}100 \\
100\end{array}$ & 0.488 \\
\hline 4 & $\begin{array}{l}\text { Income } \\
\text { Less minimum wage } \\
\text { More minimum wage }\end{array}$ & $\begin{array}{l}29 \\
18\end{array}$ & $\begin{array}{l}58.0 \\
52.9\end{array}$ & $\begin{array}{l}21 \\
16\end{array}$ & $\begin{array}{l}42.0 \\
47.1\end{array}$ & $\begin{array}{l}50 \\
34\end{array}$ & $\begin{array}{l}100 \\
100\end{array}$ & 0.647 \\
\hline
\end{tabular}

Table 2. Distribution of the relationship characteristics of children with special needs with the ability to maintain personal hygiene in Bogor $(n=84)$.

\begin{tabular}{|c|c|c|c|c|c|c|c|c|}
\hline No. & $\begin{array}{l}\text { Children with special } \\
\text { needs characteristics }\end{array}$ & & & $\begin{array}{r}\text { Pers } \\
\text { Nc }\end{array}$ & lent & & & P-value \\
\hline & variables & $\mathbf{N}$ & $\%$ & $\mathrm{~N}$ & $\%$ & n & $\%$ & \\
\hline 1 & Physical condition & & & & & & & \\
\hline & Deaf & 17 & 36.2 & 3 & 8.1 & 20 & 23.8 & \\
\hline & Blind & 2 & 4.3 & 2 & 5.4 & 4 & 4.8 & \\
\hline & Physical disabled & 4 & 8.5 & 5 & 13.5 & 9 & 10.7 & \\
\hline & Mentally disabled & 21 & 44.7 & 20 & 54.1 & 41 & 48.8 & $0.004^{*}$ \\
\hline & Autism & 3 & 6.4 & 4 & 10.8 & 7 & 8.3 & \\
\hline & ADHD & 0 & 0.0 & 2 & 5.4 & 2 & 2.4 & \\
\hline & Difficulties in learning & 0 & 0.0 & 1 & 2.7 & 1 & 1.2 & \\
\hline 2 & Cognitive ability & & & & & & & \\
\hline & $\mathrm{IQ}<25$ & 0 & 0.00 & 2 & 5.4 & 2 & 2.4 & \\
\hline & $\mathrm{IQ}>25-50$ & 16 & 34.0 & 13 & 35.1 & 29 & 34.5 & 0.314 \\
\hline & $\mathrm{IQ}>50$ & 31 & 66.0 & 22 & 59.5 & 53 & 63.1 & \\
\hline 3 & Age & & & & & & & \\
\hline & 6-12 years & 24 & 51.1 & 23 & 48.9 & 47 & 100 & \\
\hline & $>12-18$ years & 23 & 62.2 & 14 & 37.8 & 37 & 100 & 0.308 \\
\hline 4 & Gender & & & & & & & \\
\hline & Male & 23 & 51.1 & 22 & 48.9 & 45 & 100 & 0336 \\
\hline & Female & 24 & 61.5 & 15 & 38.5 & 39 & 100 & 0.336 \\
\hline
\end{tabular}

*P-value $<0.05$ 
Table 3. Distribution of the relationship between family support and children with the ability to maintain personal hygiene in Bogor $(\mathbf{n}=84)$.

\begin{tabular}{|c|c|c|c|c|c|c|c|c|c|}
\hline No. & Family support variable & & & $\begin{array}{l}\mathrm{Pe} \\
\mathrm{No}\end{array}$ & $\begin{array}{l}\text { ene } \\
\text { lent }\end{array}$ & & & OR 95\%CI & P-value \\
\hline & & $\mathbf{N}$ & $\%$ & $\mathbf{N}$ & $\%$ & n & $\%$ & & \\
\hline 1 & $\begin{array}{l}\text { Family support } \\
\text { Good } \\
\text { Not good }\end{array}$ & $\begin{array}{l}33 \\
14\end{array}$ & $\begin{array}{l}73.3 \\
35.9\end{array}$ & $\begin{array}{l}12 \\
25\end{array}$ & $\begin{array}{l}26.7 \\
64.1\end{array}$ & $\begin{array}{l}45 \\
39\end{array}$ & $\begin{array}{l}100 \\
100\end{array}$ & $\begin{array}{c}4.911 \\
(1.938-12.444)\end{array}$ & $0.001 *$ \\
\hline 2 & $\begin{array}{l}\text { Information support } \\
\text { Good } \\
\text { Not good }\end{array}$ & $\begin{array}{l}34 \\
13\end{array}$ & $\begin{array}{l}73.9 \\
34.2\end{array}$ & $\begin{array}{l}12 \\
25\end{array}$ & $\begin{array}{l}26.1 \\
65.8\end{array}$ & $\begin{array}{l}26 \\
38\end{array}$ & $\begin{array}{l}100 \\
100\end{array}$ & $\begin{array}{c}5.449 \\
(2.130-13.939)\end{array}$ & $0.000^{*}$ \\
\hline 3 & $\begin{array}{l}\text { Instrumental support } \\
\text { Good } \\
\text { Not good }\end{array}$ & $\begin{array}{l}36 \\
11\end{array}$ & $\begin{array}{l}72.0 \\
32.4\end{array}$ & $\begin{array}{l}14 \\
23\end{array}$ & $\begin{array}{l}28.0 \\
67.6\end{array}$ & $\begin{array}{l}50 \\
35\end{array}$ & $\begin{array}{l}100 \\
100\end{array}$ & $\begin{array}{c}5.377 \\
(2.085-13.865)\end{array}$ & $0.000^{*}$ \\
\hline 4 & $\begin{array}{l}\text { Emotional support } \\
\text { Good } \\
\text { Not good }\end{array}$ & $\begin{array}{l}33 \\
14\end{array}$ & $\begin{array}{l}71.7 \\
36.8\end{array}$ & $\begin{array}{l}13 \\
24\end{array}$ & $\begin{array}{l}28.3 \\
63.2\end{array}$ & $\begin{array}{l}46 \\
38\end{array}$ & $\begin{array}{l}100 \\
100\end{array}$ & $\begin{array}{c}4.352 \\
(1.734-10.919)\end{array}$ & $0.001^{*}$ \\
\hline 5 & $\begin{array}{l}\text { Appreciation support } \\
\text { Good } \\
\text { Not good }\end{array}$ & $\begin{array}{c}39 \\
8\end{array}$ & $\begin{array}{l}83.0 \\
21.6\end{array}$ & $\begin{array}{c}8 \\
29\end{array}$ & $\begin{array}{l}17.0 \\
78.4\end{array}$ & $\begin{array}{l}47 \\
37\end{array}$ & $\begin{array}{l}100 \\
100\end{array}$ & $\begin{array}{c}17.672 \\
(5.933-52.639)\end{array}$ & $0.001^{*}$ \\
\hline
\end{tabular}

\section{Conclusions}

Our results showed that there is a significant relationship between family support and personal hygiene in children with special needs. Additionally, there is a significant relationship between information, instrumental, emotional, and appreciation support and the personal hygiene of children with special needs. The most dominant family support types for personal hygiene are appreciation and information support.

\section{References}

1. Wilson D, Wong DL, Hockenberry MJ, Wilson D. Wong's nursing care of infants and children. 10th ed. St Louis: Mosby; 2015.

2. The Ministry of Women's Empowerment and Child Protection Republic of Indonesia. Panduan penanganan anak berkebutuhan khusus (orang tua, keluarga, dan masyarakat); 2013. Available from: https://www.kemenpppa.go.id/lib/ uploads/list/b3401-panduan-penanganan-abk-bagi-pendamping-_orang-tuakeluarga-dan-masyarakat.pdf

3. World Health Organization. World report on disability. World Health Organization and The World Bank; 2011. Available from: https://www. who.int/disabilities/world_report/2011/report.pdf

4. The Ministry of Health Republic of Indonesia. Penyandang disabilitas pada anak. Infodatin Pusat Data dan Informasi Kementerian Kesehatan RI
(The Ministry of Health Republic of Indonesia); 2014. Avaliable from: https://www.kemkes.go.id/resources/do wnload/pusdatin/infodatin/infodatin_di sabilitas.pdf

5. The Ministry of Health Republic of Indonesia. Riset kesehatan dasar 2013. Badan Penelitian dan Pengembangan Kesehatan Kementerian Kesehatan RI (The Ministry of Health Republic of Indonesa); 2013. Available from: https://www.kemkes.go.id/resources/do wnload/general/Hasil\%20Riskesdas $\% 2$ 02013.pdf.

6. World Health Organization. International classification of functioning, disability and health (ICF). World Health Organization Geneva; 2001. Available from: https://apps.who.int/iris/bitstream/handle/10665/42407/9241545429.pdf;jsessionid=1B37E4AD8FE17E4791B80A0 10BF9D96E? sequence $=1$.

7. Sparrow SS. Vineland adaptive behavior scales. In: Kreutzer JS, DeLuca J, Caplan B (eds.) Encyclopedia of Clinical Neuropsychology. New York: Springer; 2011

8. Hall HR, Graff JC. The relationships among adaptive behaviors of children with autism, family support, parenting stress, and coping. Issues Compr Pediatr Nurs 2011;34:4-25.

9. Mazecaite-Vaitilaviciene L, Owens J. Children with disabilities at risk of poor oral health in The Republic of Lithuania: A retrospective descriptive service evaluation. World Med Health Policy 2018;10:246-58.
10. Limeres J, Martínez F, Feijoo JF, et al. A new indicator of the oral hygiene habits of disabled persons: Relevance of the carer's personal appearance and interest in oral health. Int $\mathrm{J}$ Dent Hyg 2014;12:121-6.

11. Wertalik JL, Kubina RM. Interventions to improve personal care skills for individuals with autism: A review of the literature. Rev J Autism Dev Disord 2017;4:50-60.

12. Koutroulis I, Pyle T, Kopylov D, et al. The association between bathing habits and severity of atopic dermatitis in children. Clin Pediatr 2016;55:176-81.

13. World Health Organization. Diet, nutrition and the prevention of chronic disease. Report of a Joint WHO/FAO Expert Consultation. Report No: 916; 2003. Available from: https://apps.who. int/iris/bitstream/handle/10665/42665/ WHO TRS 916.pdf? sequence $=1$.

14. De Jongh $\overline{A D}$, Van Houtem C, Van Der Schoof M, et al. Oral health status, treatment needs, and obstacles to dental care among noninstitutionalized children with severe mental disabilities in the Netherlands. Spec Care Dentist 2008;28:111-5.

15. Francis K, Mannion A, Leader G. The assessment and treatment of toileting difficulties in individuals with autism spectrum disorder and other developmental disabilities. Rev J Autism Dev Disord 2017;4:190-204.

16. Friedman MM, Bowden VR, Jones EG. Family nursing textbook: Research, theory, and practice. Jakarta: EGC; 2010.

17. Aldersey HM, Turnbull AP, Turnbull III 
HR. Family support in Kinshasa, Democratic Republic of the Congo. J Policy Pract Intel 2016;13:23-32.

18. Stewart M, Masuda JR, Letourneau N, et al. "I want to meet other kids like me": Support needs of children with asthma and allergies. Issues Compr Pediatr Nurs 2011;34:62-78.

19. Lestari S, Yani DI, Nurhidayah I. Kebutuhan orang tua dengan anak disabilitas. J Nurs Care 2018;1:50-9.

20. Ramawati D, Allenidekania A, Besral B. Kemampuan perawatan diri anak tuna grahita berdasarkan faktor eksternal dan internal anak. Jurnal Keperawatan Indonesia 2012;15:89-96.

21. Ananditha AC, Allenidekania A, Syahreni E. Pengaruh pembelajaran dengan media buku cerita bergambar terhadap activity daily living: toileting pada anak tunagrahita. [Unpublished Thesis].
Depok: Universitas Indonesia; 2013.

22. Rinald K, Mirenda P. Effectiveness of a modified rapid toilet training workshop for parents of children with developmental disabilities. Res Dev Disabil 2012;33:933-43.

23. Polit DF, Beck C. Nursing research: Generating and assessing evidence for nursing practice. 9th ed. Philadelphia: Lippincott Williams and Wilkins; 2012.

24. Desiningrum DR. Psikologi anak berkebutuhan khusus. Yogyakarta: Psikosain; 2016. Available from: http://eprints. undip.ac.id/51629/1/Dinie_Ratri_Buku_ Psikologi_ABK_2016.pdf

25. Notoatmodjo S. Prinsip-prinsip dasar ilmu kesehatan masyarakat. Jakarta: PT Rineka Cipta; 2003.

26. Davis-Kean PE. The influence of parent education and family income on child achievement: The indirect role of parental expectations and the home environment. J Fam Psychol. 2005;19:294-304.

27. Hockenberry MJ, Wilson D. Wong's essentials of pediatric nursing. 8th ed. St. Louis: Mosby Elsevier; 2009.

28. Cohen SR, Holloway SD, DomínguezPareto I, Kuppermann M. Receiving or believing in family support? Contributors to the life quality of latino and non-latino families of children with intellectual disability. J Intell Disabil Res 2014;58:333-45.

29. Mundhenke L, Hermansson L, Nätterlund BS. Experiences of Swedish children with disabilities: Activities and social support in daily life. Scand J Occup Ther 2010;17:64-71.

30. Låftman SB, Östberg V. The pros and cons of social relations: An analysis of adolescents' health complaints. Soc Sci Med 2006;63:611-23. 